\title{
Armenia: Report on Observance of Standards and Codes-FATF Recommendations for Anti-Money Laundering and Combating the Financing of Terrorism
}

This Report on the Observance of Standards and Codes on the FATF Recommendations for Anti-Money Laundering and Combating the Financing of Terrorism for Armenia was prepared by a staff team of the International Monetary Fund using the assessment methodology adopted by the FATF in February 2004 and endorsed by the Executive Board of the IMF in March 2004. The views expressed in this document, as well as in the full assessment report, are those of the staff team and do not necessarily reflect the views of the Government of Armenia or the Executive Board of the IMF.

To assist the IMF in evaluating the publication policy, reader comments are invited and may be sent by e-mail to publicationpolicy@imf.org.

Copies of this report are available to the public from

International Monetary Fund $\bullet$ Publication Services

700 19th Street, N.W. • Washington, D.C. 20431

Telephone: (202) 6237430 • Telefax: (202) 6237201

E-mail: publications@imf.org •Internet: http://www.imf.org

Price: $\$ 18.00$ a copy

\section{International Monetary Fund Washington, D.C.}




\title{
INTERNATIONAL MONETARY FUND
}

\begin{abstract}
ARMENIA
Report on Observance of Standards and Codes (ROSC)—FATF Recommendations for Anti-Money Laundering and Combating the Financing of Terrorism (AML/CFT)

Prepared by the Legal Department

Approved by Sean Hagan
\end{abstract}

November 2009 


\begin{tabular}{|c|c|}
\hline & ABBREVIATIONS \\
\hline $\mathrm{AML} / \mathrm{CFT}$ & Anti-Money Laundering and Combating the Financing of Terrorism \\
\hline $\mathrm{APC}$ & Administrative Procedure Code \\
\hline BL & Banking Law \\
\hline $\mathrm{BCP}$ & Basel Core Principles \\
\hline $\mathrm{CC}$ & Criminal Code \\
\hline CBA & Central Bank of Armenia \\
\hline CDD & Customer Due Diligence \\
\hline $\mathrm{CPC}$ & Criminal Procedure Code \\
\hline DNFBP & Designated Non-Financial Businesses and Professions \\
\hline FATF & Financial Action Task Force \\
\hline FMC & Financial Monitoring Center \\
\hline FSAP & Financial Sector Assessment Program \\
\hline KYC & Know your Customer/client \\
\hline LBS & Law on Banking Secrecy \\
\hline LOSA & Law on Operational and Search Activities \\
\hline MoF & Ministry of Finance \\
\hline MoFA & Ministry of Foreign Affairs \\
\hline MoJ & Ministry of Justice \\
\hline $\mathrm{MoU}$ & Memorandum of Understanding \\
\hline ML & Money Laundering \\
\hline MLA & Mutual Legal Assistance \\
\hline NSS & National Security Service \\
\hline NPO & Non-Profit Organization \\
\hline NGO & Non Governmental Organizations \\
\hline PEP & Politically-Exposed Person \\
\hline PSO & Payment and Settlement Organizations \\
\hline RA & Republic of Armenia \\
\hline ROSC & Report on Observance of Standards and Codes \\
\hline STR & Suspicious Transaction Report \\
\hline $\mathrm{TF}$ & Terrorism Financing \\
\hline TTR & Transaction Threshold Report \\
\hline UN & United Nations Organization \\
\hline UNSCR & United Nations Security Council Resolution \\
\hline
\end{tabular}




\section{A. Introduction}

1. This Report on the Observance of Standards and Codes for the FATF 40

Recommendations for Anti-Money Laundering (AML) and 9 Special Recommendations on Combating the Financing of Terrorism (CFT) was prepared by the $\mathrm{IMF}^{1}$. The report provides a summary of the AML/CFT measures in place in Armenia and of the level of compliance with the FATF 40+9 Recommendations, and contains recommendations on how the AML/CFT system could be strengthened. The assessment is based on the information available at the time of the mission from February 23-March 10, 2009 and was conducted using the 2004 Assessment Methodology. The Detailed Assessment Report (DAR) on which this document is based was adopted by the MONEYVAL plenary on September 22, 2009. The views expressed here, as well as in the full assessment report, are those of the staff team and do not necessarily reflect the views of the Government of Armenia or the Executive Board of the IMF.

\section{B. Key Findings}

2. Armenia has made considerable improvements in its AML/CFT framework in a relatively short timeframe, particularly by replacing a first AML/CFT law, enacted in 2005, with a more comprehensive law, which was passed in 2008. The new law needs to be implemented effectively, especially by DNFBPs. The authorities have not yet conducted a systemic assessment of ML and TF threats and risks in Armenia to support the development and implementation of a robust AML/CFT regime.

3. Armenia's financial system remains small and bank-dominated. Total assets of the banking sector accounted for approximately 91 percent of the assets in the financial system. Most banks are domestically owned but there is a major foreign presence in the system. The non bank financial sector plays a small role in financial intermediation.

4. The risk that the financial system can be used in the "layering" stage of ML or to launder proceeds is not high (although certain financial instruments, such as bearer securities pose a risk of being used for ML). Armenia appears to be more vulnerable to the "integration" stage of ML, because of the highly cash-based economy, the significant volume of remittances from abroad, the relevant level of proceed-generating crime and the lack of adequate AML/CFT mechanisms in certain sector, such as real estate.

5. Although Armenia has established a mechanism to boost coordination among the various authorities responsible for AML/CFT, in the form of an Interagency commission, and

\footnotetext{
${ }^{1}$ The assessment team consisted of Giuseppe Lombardo (mission chief) and Francisco Figueroa (all of LEG); Gabriele Dunker and Lisa Kelaart-Courtney (consultants).
} 
political commitment in fighting against ML and TF is strong, more focus should be placed on an overall assessment of the risk of ML Armenia is exposed to because of the above mentioned vulnerabilities.

6. The risk of TF is extremely low.

7. The Financial Intelligence Unit - the Financial Monitoring Center (FMC), established within the Central Bank of Armenia - is a young though very knowledgeable and active FIU. However it is understaffed to properly undertake the new responsibilities assigned to it by the new AML/CFT law.

8. The money laundering offence is criminalized broadly in line with the international standard. A range of technical deficiencies have been identified with respect to the terrorism offense. The seizure and confiscation framework needs to be further strengthened, in particular with respect to the predicate offenses. Armenia should revisit its response to UNSCRs 1267 and 1373 as the current mechanism is inadequate.

9. The Vienna, Palermo and SFT Conventions have been ratified by Armenia and many, albeit not all, provisions of the Conventions have already been implemented.

10. The Armenian AML/CFT preventive measures for financial institutions operating in the financial system are comprehensive, provide for risk-based elements, and relatively close to the FATF Recommendations. However, implementation across all sectors is evolving, particularly for the non-banking sectors. In general, the supervisory authorities are conducting AML/CFT on-site inspections which are largely focused on regulatory compliance.

\section{Legal Systems and Related Institutional Measures}

11. Armenia's criminal provisions for money laundering are basically sound and address many criteria under the FATF standard. Although there are some convictions, it has not yet been ascertained through a court judgment that money laundering can be prosecuted as an autonomous stand alone offense and in the absence of a conviction for the predicate offense. Legal persons are not subject to criminal liability under Armenian law. The number of ML criminal investigations, prosecutions and convictions is low if compared to the number of criminal investigations, prosecutions and convictions for the main proceeds-generating predicate offenses. The standard of proof applied by the courts to establish that assets originate from crime remains a challenge.

12. The criminal provisions relating to terrorism financing are broadly in line with the TF Convention. However, the provisions should be amended to be applicable to all nine Conventions and Protocols Annexed to the TF Convention and to cover the notion of "funds" as defined in the Convention. Moreover, the TF criminal provision is not in line with FATF Special Recommendation II, because it does not extend to situations in which property or 
funds are provided to individual terrorists or terrorist organizations without the intention or knowledge that the funds will be used in the commission a specific act of terrorism.

13. The provisions relating to the confiscation of property involved in the commission of money laundering, terrorism financing and predicate offenses meet several albeit not all criteria of the international standard. Most notably, confiscation is not available for all FATF designated predicate offenses. Armenian financial secrecy is regulated by a number of different provisions, which have not been harmonized and in practice are interpreted in the most restrictive way. This creates some uncertainties in the application of the legal framework and limits the power of law enforcement agencies to identify and trace property that is or may become subject to confiscation, especially prior to the identification of a suspect or where the information sought relates to a person other than the suspect. The confiscation and seizing provisions do not seem to be implemented effectively.

14. The freezing mechanism applied by Armenia to address its obligations under UNSCR 1267 and 1373 is deficient; the AML/CFT law provides for the freezing of terrorist-related assets only for a limited period of time, after which domestic proceedings for a specific offense must be instigated, including in the case of designations pursuant to UNSCR 1267.

\section{Preventive Measures - Financial Institutions}

15. The AML/CFT Law establishes the principal preventive obligations for financial institutions broadly in line with the FATF Recommendations. The AML/CFT legal provisions are implemented through detailed requirements contained in the regulations issued by the Central Bank of Armenia (CBA), the sole regulatory authority of financial institutions. Other sector specific laws complement the AML/CFT obligations. Both laws and the implementing regulations are enforceable and sanctionable in accordance with the provisions established in the applicable AML/CFT Law and financial sector laws. The CBA, through the FMC, issues guidance to financial institutions to improve the implementation of the preventive measures.

16. The AML/CFT law and regulations cover all financial institutions and activities as set out under the FATF definition of financial institution, and impose detailed AML/CFT requirements on the financial sector for; inter alia, CDD including for PEPs, record-keeping, correspondent banking, unusual, large and suspicious transaction reporting, internal controls, compliance management arrangements, and training. However, there are a number of areas where the requirements do not comply with the FATF Recommendations. These include the lack of: prohibition for opening a business relationship through or using bearer bank records or other bearer securities; effective risk management procedures concerning conditions under which a customer is permitted to utilize the business relationship prior to CDD verification; and CDD measures to existing customers on the basis of materiality and risk. In addition, there are no requirements with respect to third parties and introduced business. Finally, 
measures dealing with compliance management arrangements and internal programs and controls are deficient.

17. Implementation of the preventive/regulatory requirements by financial institutions varies, for example, slightly more advanced in the banking sector, but less so in other important and risky sectors (i.e., securities, insurance, foreign exchange offices, and money remitters). The AML/CFT Law and regulations provide for risk-based elements for purposes of CDD. Going forward, these risk-based provisions could be better supported with sectorspecific guidelines, and refinements to the simplified CDD regime allowed for in the regulations. CDD requirements for introduced business and third parties should also be revised to provide for more comprehensive measures. There is a clear obligation to report suspicions of ML and FT; however, the level of suspicious transaction reports is very low and restricted mainly to the banking sector.

18. The CBA, through the Financial Supervision Department (FSD) is the sole supervisory authority responsible for AML/CFT compliance supervision and for the enforcement of the preventive requirements of the AML/CFT Law and regulations. The CBA has broad powers to obtain access to and inspect financial institutions under its jurisdiction and to sanction for noncompliance. In practice, the CBA has applied administrative sanctions, including fines for noncompliance with the AML/CFT Law and implementing regulations. The FSD has implemented a fairly comprehensive system for supervision; however, it could enhance this system by updating supervisory tools like the examination manual and related examination procedures to incorporate risk-based elements and the requirements of the 2008 AML/CFT Law.

19. This supervisory process could benefit from the introduction of more risk-based processes and updated examination manuals/procedures in line with the 2008 AML/CFT Law and implementing regulations. The Armenian authorities acknowledge the need to update their supervisory manuals and examination procedures in line with their risk-based approach to supervision and the 2008 AML/CFT Law (e.g. for the credit organizations, securities, insurance, foreign exchange offices, and money services sectors).

\section{E. Preventive Measures - Designated Non-Financial Businesses and Professions}

20. All DNFBPs as described in the FATF definition are encompassed within the AML/CFT Law as reporting entities. The preventive measures for DNFBPs set forth in the AML/CFT law are similar to those for financial institutions; however the additional regulations, rules or guidance in place for financial institutions to complement the requirements of the AML/CFT law are not applicable to DNFBPs. Consequently, the DNFBPs legal regime of preventive measures is substantially deficient. No obligations for the treatment of politically exposed persons (PEPs) or any other high risk customer or business transaction is in place and there are no legal or regulatory measures to prevent 
criminals or their associates from holding or being beneficial owners of a significant or controlling interest, holding a management function, in or being an operator of a casino.

21. Implementation of preventive measures by DNFBPs is inadequate across the sector and no DNFBP has ever yet filed a suspicious transaction report. A number of DNFBPs including independent lawyers and firms providing legal services, dealers in precious metals or dealers in precious stones and independent accountants and accounting firms are unlicensed and unsupervised for compliance with AML/CFT obligations. Further, the licensing and monitoring regime in place for the remaining DNFBPs is not focused on $\mathrm{AML} / \mathrm{CFT}$ or in some instances such as advocates (attorneys) there is a complete absence of a supervisory or monitoring framework. Overall, minimal resources of authorities, and in some instances limited technical expertise, were in place, with a view to improving AML/CFT compliance. The trust and company service providers (TCSP) sector is not established in Armenia, although TCSPs are subject to the AML/CFT law.

22. For the most part, the effectiveness of implementation of the existing requirements and obligations is marginal with DNFBPs on a whole reflecting very little knowledge or understanding of their obligations and very little evidence of practice of their obligations.

\section{F. Legal Persons and Arrangements \& Non-Profit Organizations}

23. Armenia has measures in place that ensure that information on beneficial ownership of legal entities is obtained and maintained. However, due to the very recent enforcement of those measures, it could not be determined that they are already implemented effectively. Armenian law does not recognize trusts or any other forms of legal arrangements. Armenia is also not a signatory to the Hague Convention on Laws Applicable to Trusts and on their Recognition.

24. Both foreign and domestic NPOs operating within Armenia are required to be registered with the Legal Persons State Register of the Republic of Armenia Ministry of Justice (State Register). NPOs take the form of charities, foundations or other social organizations, and over 5,500 NPOs were registered with the State Registry at the time of the assessment. Although no vulnerabilities to abuse for TF purposes were identified by authorities when a review of the applicable laws was undertaken, it is recommended that the authorities undertake outreach to, and a review, of the sector.

\section{G. National and International Co-operation}

25. Significant improvements in the national cooperation framework and practices have taken place over the past few years with the establishment of a national body with a wide mandate in relation to financial crime. Known as the "Interagency Standing Commission on Fight against Counterfeiting Currency, Plastic Cards, and Other Payment Instruments, against the Money Laundering, as well as Financing Terrorism in the Republic of Armenia" (Interagency Commission), it is the principal forum for cooperation and coordination 
between domestic authorities. The Interagency Commission's membership represents all relevant authorities although consultation with the financial institutions and other businesses subject to supervision for AML/CFT purposes is passive with only the Association of Banks of Armenia formally represented.

26. The Interagency Commission's mandate includes but is not limited to AML and CFT policy considerations and directives; the oversight and evaluation of the effectiveness of implemented policies and programs on AML/CFT, information sharing on trends and methodologies and educational programs. However, the Interagency Commission has not undertaken an analysis of the risk of ML/TF in Armenia to determine vulnerabilities, sectors at risk, types of predicate offenses committed in Armenia that could generate proceeds. Such assessment should serve as a basis for streamlining its AML/CFT strategy and further develop the work already undertaken.

27. Additionally, formal gateways are in place through bilateral Memorandums of Understanding (MoUs), specific to ML and TF, between the financial intelligence unit, known as the Financial Monitoring Center, and the National Security Service, the Police, State Revenue Service and the Prosecutor's Office. The MoUs all have the same parameters for co-operation in relation to the exchange of information on suspicious $\mathrm{ML} / \mathrm{TF}$ transactions; joint discussions on suspicious ML/TF transactions; mutual assistance in drafting the rules, guides and other methodological materials on combating the ML/TF; joint activities on maintaining case statistics and development of typologies; and the implementation of joint training, education and consulting programs on combating the $\mathrm{ML} / \mathrm{TF}$.

28. The legal framework for mutual legal assistance (MLA) and extradition is sound and the provision of MLA is not subject to any unreasonable or unduly restrictive conditions. Even though not required by law, in practice Armenia provides any form of MLA only subject to dual criminality. This also entails that the shortcomings noted with respect to the money laundering and terrorism financing provisions may impact Armenia's ability to provide mutual legal assistance, for example if the request involves a legal entity. Equally, the limitations noted in regard to provisional measures (including seizing, freezing and tracing), confiscation and financial secrecy can affect the provision of MLA. Both ML and $\mathrm{TF}$ are extraditable offenses under Armenian law. Armenia has not received or made any requests for MLA, including extradition request, relating to ML or FT.

\section{H. Other Issues}

29. The lack of comprehensive and meaningful statistics precluded a meaningful assessment of the level of effectiveness of AML/CFT measures across all sectors. There is also a present need for additional human resources, particularly in the area of AML/CFT supervision and within the FMC, and need for specific AML/CFT training for law enforcement authorities, particularly the NSS. 


\section{Summary Table of Observance and Key Recommendations}

\begin{tabular}{|c|c|}
\hline FATF 40+9 Recommendations ${ }^{2}$ & Key Assessor Recommendations \\
\hline \multicolumn{2}{|r|}{ 1. Legal System and Related Institutional Measures } \\
\hline $\begin{array}{c}\text { Criminalization of Money } \\
\text { Laundering } \\
\text { R.1 - LC } \\
\text { R. } 2 \text { - LC }\end{array}$ & $\begin{array}{l}\text { - Undertake appropriate initiatives (such as outreach or training, for example) } \\
\text { to all authorities involved in investigating, prosecuting and adjudicating } \\
\text { money laundering (ML) cases to: (1) assess what barriers exists for } \\
\text { prosecuting ML, for example whether and to what extent the level of proof } \\
\text { applied to show that property stems from the commission of a specific } \\
\text { predicate offence poses an obstacle to obtaining convictions for stand-alone } \\
\text { money laundering; and (2) to further raise the awareness on the statutory } \\
\text { requirements of the ML provisions; } \\
\text { - Amend the law to provide for criminal liability of corporate entities. }\end{array}$ \\
\hline $\begin{array}{c}\text { Criminalization of Terrorist } \\
\text { Financing } \\
\text { SR.II - PC }\end{array}$ & $\begin{array}{l}\text { - Amend the definition of "terrorism" pursuant to Article } 217 \text { CC (1) to cover } \\
\text { all terrorism offenses as defined in the nine Conventions and Protocols listed } \\
\text { in the Annex to the TF Convention and (2) to include a reference to } \\
\text { "international organizations", as required by Article } 2 \text { of the TF Convention; } \\
\text { - Amend Article 217.1. CC to cover situations in which the property or funds } \\
\text { are provided or collected generally for use by an individual terrorist or a } \\
\text { terrorist organization when there is no intention or knowledge that the funds } \\
\text { or property will be used in the commission a specific act of terrorism. }\end{array}$ \\
\hline $\begin{array}{c}\text { Confiscation, freezing, and seizing } \\
\text { of proceeds of crime } \\
\text { R.3 - PC }\end{array}$ & $\begin{array}{l}\text { - With respect to all predicate offenses not covered by Articles 55(3) CC, } \\
\text { measures should be put in place to allow for the confiscation of proceeds from } \\
\text { and instrumentalities used or intended to be used for the commission of the } \\
\text { offenses as well as of legitimate assets equivalent in value to such property; } \\
\text { - Article 55(3) CC should be amended to allow for the confiscation of property } \\
\text { regardless of whether it is held or owned by the defendant or a third party; } \\
\text { - Put in place measures to allow for the seizing of legitimate assets equivalent in } \\
\text { value to proceeds from or instrumentalities used or intended for use in the } \\
\text { commission of ML, TF or predicate offenses; } \\
\text { - The law enforcement authorities should ensure that provisional measures } \\
\text { with respect to property that may become subject to confiscation are } \\
\text { implemented effectively in the context of inquests/investigations/pre-trials for } \\
\text { ML and TF; } \\
\text { - Armenian authorities should reconsider their approach to confiscation with a } \\
\text { view to increasing the number of confiscation actions and to encourage a } \\
\text { more frequent use of the confiscation provisions. }\end{array}$ \\
\hline $\begin{array}{c}\text { Freezing of funds used for terrorist } \\
\text { financing } \\
\text { SR.III - NC }\end{array}$ & $\begin{array}{l}\text { - Armenia should review the freezing mechanisms set forth in Article } 25 \\
\text { AML/CFT law that are meant to implement obligations under UNSCR } 1267 \text {, } \\
\text { UNSCR } 1373 \text { and SRIII. In particular, Armenian law should provide for } \\
\text { meeting the designation and freezing responsibilities set forth in the UN } \\
\text { Resolution in all instances regardless of whether it is possible to instigate an } \\
\text { investigation or prosecution of a terrorist offence. It should provide an } \\
\text { indefinite freezing mechanism that is available regardless of the initiation or }\end{array}$ \\
\hline
\end{tabular}

\footnotetext{
${ }^{2}$ Compliant (C): the Recommendation is fully observed with respect to all essential criteria. Largely compliant (LC): there are only minor shortcomings, with a large majority of the essential criteria being fully met. Partially compliant (PC): the country has taken some substantive action and complies with some of the essential criteria. Non-compliant (NC): there are major shortcomings, with a large majority of the essential criteria not being met. Not applicable (NA): a requirement or part of a requirement does not apply, due to the structural, legal or institutional features of a country.
} 


\begin{tabular}{|c|c|}
\hline & $\begin{array}{l}\text { outcome of a domestic criminal proceeding and does not allow for any } \\
\text { discretion in implementing a freeze in case of a match with the UN Security } \\
\text { Council lists; } \\
\text { - The freezing measures should apply not only to funds but also to any financial } \\
\text { assets and property of every kind, as defined in the FATF standard and the } \\
\text { Interpretative Note to Special Recommendation III; } \\
\text { - The FMC should issue formal guidance to reporting entities and other } \\
\text { persons or entities that may be holding targeted funds or other assets } \\
\text { concerning their obligations in taking freezing actions pursuant to UNSCR } \\
1373 \text { and Article } 25 \text { AML/CFT Law. }\end{array}$ \\
\hline $\begin{array}{c}\text { The Financial Intelligence Unit and } \\
\text { its functions } \\
\text { R.26 - LC }\end{array}$ & $\begin{array}{l}\text { - Increase the number of staff, particularly of the Analysis division; } \\
\text { - Consider establishing a unit (or a sub-unit in the Analysis division) to deal } \\
\text { specifically with the analysis of TRs; } \\
\text { - Outreach to DNFBPs protected by professional secrecy (in particular lawyers, } \\
\text { accountants and auditors) to clarify the ambit of application of Article } 4 \text {, } \\
\text { paragraph } 3 \text { of the AML law and, if needed, modify the text of the law to } \\
\text { ensure that the reference to professional secrecy does not hamper ability of } \\
\text { FMC to request additional information. }\end{array}$ \\
\hline $\begin{array}{l}\text { Law enforcement, prosecution and } \\
\text { other competent authorities } \\
\text { R.27 - LC } \\
\text { R.28 - PC }\end{array}$ & $\begin{array}{l}\text { - The CPC should be amended to provide for a general power of the law } \\
\text { enforcement authorities or the courts to compel the production of documents } \\
\text { and information in ML and TF cases, including also in cases where the } \\
\text { information is requested from a witness or a person other than the injured, or } \\
\text { the plaintiff, suspect or accused; } \\
\text { - Harmonize Articles } 10 \text { of the LBS with Article } 29 \text { of the LOSA and Articles } \\
13.1 \text { of the LBS with } 13 \text { of the AML/CFT Law so that they provide the same } \\
\text { conditions with respect to access to information covered by financial secrecy } \\
\text { and to ensure that law enforcement authorities have adequate powers to } \\
\text { access and compel production of information, transaction records, account } \\
\text { files and other documents or information that is covered by financial secrecy, } \\
\text { especially in cases where a suspect has not yet been identified or where the } \\
\text { information is sought with respect to persons other than the suspect. }\end{array}$ \\
\hline $\begin{array}{c}\text { Cross Border Declaration or } \\
\text { disclosure } \\
\text { SR IX- PC }\end{array}$ & $\begin{array}{l}\text { Provide Customs authorities with the power to stop or restrain currency } \\
\text { where there is a suspicion of money laundering or terrorist financing; } \\
\text { - Increase the level of sanctions; } \\
\text { - Introduce freezing requirements envisaged by SRIII and the UNSCRs in the } \\
\text { case of persons who are carrying out a physical cross-border transportation of } \\
\text { currency or bearer negotiable instrument that are related to TF; } \\
\text { - Analyze the information collected under the declaration requirements to } \\
\text { develop AML/CFT intelligence. }\end{array}$ \\
\hline \multicolumn{2}{|r|}{ 2. Preventive Measures: Financial Institutions } \\
\hline $\begin{array}{c}\text { Risk of money laundering or } \\
\text { terrorist financing }\end{array}$ & \\
\hline $\begin{array}{l}\text { Customer due diligence, including } \\
\text { enhanced or reduced measures } \\
\text { R.5 - PC } \\
\text { R.6 - LC } \\
\text { R.7 - C } \\
\text { R.8 - LC }\end{array}$ & $\begin{array}{l}\text { - Prohibit bearer bank books and certificates of deposit or other bearer } \\
\text { securities, by way of repealing/changing articles of the Civil Code and any } \\
\text { other regulations that make available these instruments in bearer form or } \\
\text { regulate them; } \\
\text { - Provide additional guidance to financial institutions with respect to adequate } \\
\text { timeframes for updating customer data to ensure consistent and effective } \\
\text { implementation; } \\
\text { - Provide additional guidance to specify a reasonable timeframe that financial } \\
\text { institutions should follow when obtaining identification information and } \\
\text { checking the veracity of such information in the course of establishing a } \\
\text { business relationship; } \\
\text { - Ensure financial institutions are implementing more effectively the obligations } \\
\text { imposed by the AML/CFT and implementing regulations with respect to CDD } \\
\text { measures, by way of training or other types of outreach; }\end{array}$ \\
\hline
\end{tabular}




\begin{tabular}{|c|c|}
\hline & $\begin{array}{l}\text { - Provide additional guidance/training to financial institutions in relation to the } \\
\text { enhanced ongoing monitoring procedures required by law when establishing a } \\
\text { business relationship with a PEP. }\end{array}$ \\
\hline $\begin{array}{l}\text { Third parties and introduced } \\
\text { business } \\
\text { R.9- NC }\end{array}$ & $\begin{array}{l}\text { - Amend the regulation on Minimal Requirements to establish the obligations } \\
\text { for financial institutions relying on intermediaries or third parties to: } \\
\text { - immediately obtain from the third party the necessary information } \\
\text { concerning certain elements of the CDD process (Criteria 5.3. to 5.6); } \\
\text { - take adequate steps to satisfy themselves that copies of identification data and } \\
\text { other relevant documentation relating to CDD requirements will be made } \\
\text { available from the third party upon request without delay; } \\
\text { - satisfy themselves that the third party is regulated and supervised (in } \\
\text { accordance with Recommendation } 23,24 \text {, and } 29 \text { ), and has measures in place } \\
\text { to comply with, the CDD requirements set out in R.5 and R.10; } \\
\text { - Define the notion of "specialized intermediaries or persons empowered to } \\
\text { represent third parties" in a manner that is consistent with the FATF } \\
\text { standard, in particular to limit the requirement to "third parties" that are FIs } \\
\text { or DNFBPs only and not to "persons empowered to represent third parties". }\end{array}$ \\
\hline $\begin{array}{c}\text { Financial institution secrecy or } \\
\text { confidentiality } \\
\text { R.4 - PC }\end{array}$ & $\begin{array}{l}\text { - Harmonize Article } 10 \text { of the LBS with Article } 29 \text { of the LOSA and Article } 13 \\
\text { of the AML/CFT Law with Article } 13.1 \text {. of the LBS so that they provide the } \\
\text { same conditions with respect to access to information covered by financial } \\
\text { secrecy; } \\
\text { - Ensure that access by law enforcement authorities (particularly the NSS) to } \\
\text { information covered by financial secrecy is not conditioned on the } \\
\text { identification of a "suspect" or "criminally charged" person, as this condition } \\
\text { undermines the proper performance of the NSS as the competent authority to } \\
\text { investigate ML/TF and prevents access to such information in cases relating } \\
\text { to legal persons or regarding any person other than the "suspect" or the } \\
\text { "accused"; } \\
\text { - Amend the LBS to allow financial institutions to share information covered by } \\
\text { financial secrecy where it is required by R.7, R.9 or SR.VII. }\end{array}$ \\
\hline $\begin{array}{c}\text { Record keeping and wire transfer } \\
\text { rules } \\
\text { R.10 - LC } \\
\text { SR.VII - LC }\end{array}$ & $\begin{array}{l}\text { - Provide requirements by law or regulations for establishing the threshold for } \\
\text { customer identification when a wire transfer is involved to the equivalent of } \\
€ / \$ 1,000 \text {. In this way, given the floating of the exchange rate, reporting } \\
\text { entities can ensure that the threshold remains consistent with the standard. }\end{array}$ \\
\hline $\begin{array}{l}\text { Monitoring of transactions and } \\
\text { relationships } \\
\text { R.11 - LC } \\
\text { R.21 - LC }\end{array}$ & $\begin{array}{l}\text { - Establish a clear and direct requirement for financial institutions to examine } \\
\text { as far as possible the background and purpose of complex, unusual large } \\
\text { transactions and all unusual patters of transactions which have no apparent } \\
\text { economic or visible lawful purpose as required by this recommendation; } \\
\text { - Extend the requirement to keep the findings of the examination of complex } \\
\text { and unusual large transactions also available to auditors for at least five } \\
\text { years; } \\
\text { - Provide additional training, particularly to non-bank financial institutions to } \\
\text { ensure that attention is given to all transactions that fall into the unusual, } \\
\text { large, and complex categories, regardless of any offshore and UN lists; } \\
\text { - Establish a requirement for financial institutions to: i) examine as far as } \\
\text { possible the background and purpose of transactions with persons from or in } \\
\text { countries which do not apply or insufficiently apply the FATF } \\
\text { Recommendations; ii) to document the findings; and iii) to make the written } \\
\text { findings available to assist competent authorities and auditors. }\end{array}$ \\
\hline $\begin{array}{c}\text { Suspicious transaction reports and } \\
\text { other reporting } \\
\text { R.13 - LC } \\
\text { R.14 - C } \\
\text { R.19 - C } \\
\text { R.25 - C } \\
\text { SR.IV - LC }\end{array}$ & $\begin{array}{l}\text { - Provide additional training to reporting entities to ensure that staff is } \\
\text { knowledgeable about the obligations imposed by law. Training should } \\
\text { specifically cover detection and reporting of suspicious transactions and } \\
\text { should consider typologies and trends (differentiated along the types of } \\
\text { activities, especially for DNFBPs). }\end{array}$ \\
\hline
\end{tabular}




\begin{tabular}{|c|c|}
\hline $\begin{array}{c}\text { Internal controls, compliance, audit } \\
\text { and foreign branches } \\
\text { R.15 - PC } \\
\text { R.22 - C }\end{array}$ & $\begin{array}{l}\text { - Amend the regulations to introduce an explicit and direct provision } \\
\text { highlighting the ability of the internal compliance unit/designated compliance } \\
\text { officer to have access in a timely manner to all necessary CDD information, } \\
\text { transactions records, and other relevant information; } \\
\text { - Put in place formal procedures to screen all staff by financial institutions, } \\
\text { particularly for staff in areas that are relevant to AML/CFT. These formal } \\
\text { procedures should be aimed at ensuring high standards when } \\
\text { hiring/recruiting employees; } \\
\text { - Ensure financial institutions maintain an independent and adequately } \\
\text { resourced internal audit function, particularly when audit is } \\
\text { assigned/delegated to staff other that the internal auditor. }\end{array}$ \\
\hline $\begin{array}{l}\text { Shell banks } \\
\text { R.18 - LC }\end{array}$ & $\begin{array}{l}\text { - Clarify the definition of "shell bank" in a way that is consistent with the } \\
\text { FATF standard. }\end{array}$ \\
\hline $\begin{array}{c}\text { Supervisory and oversight system- } \\
\text { competent authorities and SROs } \\
\text { Role, functions, duties and powers } \\
\text { (including sanctions) } \\
\text { R.17 - C } \\
\text { R.23 - LC } \\
\text { R.25 - LC } \\
\text { R.29 - LC }\end{array}$ & $\begin{array}{l}\text { - Strengthen AML/CFT supervision through the incorporation of risk elements } \\
\text { to the overall supervisory cycle and in particular update the supervisory } \\
\text { examination procedures to incorporate the risk-based approach to } \\
\text { supervision and the requirements of the new (2008) AML/CFT Law; } \\
\text { - Ensure that financial institutions, particularly, credit organizations, } \\
\text { insurance, securities, foreign exchange offices and money remitters are } \\
\text { adequately complying with the requirements to combat money laundering } \\
\text { and terrorist financing; } \\
\text { - Conduct frequent and ongoing AML/CFT inspections of banks organizations, } \\
\text { money transfers services (money remitters) and securities/investment firms; } \\
\text { - Update the AML/CFT examination procedures for all sectors. }\end{array}$ \\
\hline $\begin{array}{l}\text { Money value transfer services } \\
\text { SR.VI - LC }\end{array}$ & $\begin{array}{l}\text { - Follow up on the money remitter that appears to be informally operating in } \\
\text { the financial system without CBA registration and approval. }\end{array}$ \\
\hline \multicolumn{2}{|c|}{ 3.Preventive Measures: Non-Financial Businesses and Professions } \\
\hline $\begin{array}{c}\text { Customer due diligence and record- } \\
\text { keeping } \\
\text { R.12 - NC }\end{array}$ & $\begin{array}{l}\text { - Remove the threshold that limits CDD in relation to the acquisition or sales of } \\
\text { stocks or shares - for attorneys, persons providing legal services, notaries, } \\
\text { independent auditors and auditing firms, independent accountants and } \\
\text { accounting firms; } \\
\text { - Establish a direct requirement for DNFBPs to obtain information on the } \\
\text { purpose and intended nature of the business relationship regardless of } \\
\text { whether the transaction is considered high risk or not; } \\
\text { - Develop guidance for DNFBPs to ensure that there is a consistent system for } \\
\text { conducting ongoing due diligence taking into account the threats and } \\
\text { vulnerabilities of the nature, scope and operation of the DNFBPs and establish } \\
\text { the frequency for updating customer information; } \\
\text { - Establish requirements and guidance in relation to conducting enhanced due } \\
\text { diligence for higher risk customers, business relationships or transactions and } \\
\text { the application of simplified/reduced CDD measures for low risk customers, } \\
\text { including for non-resident customers; } \\
\text { - Explicitly prohibit the application of reduced CDD measures when suspicions } \\
\text { of ML/TF exist or in the event of high risk scenarios; } \\
\text { - Provide through law, rules or other enforceable means measures with respect } \\
\text { to CDD requirements for PEPs at the establishment of the business } \\
\text { relationship and during the course of such relationship; } \\
\text { - Establish a specific framework when DNFBPs may rely on third parties or } \\
\text { intermediaries to perform CDD measures; } \\
\text { - Undertake an analysis on the risks and impact of the disapplication of Article } \\
21 \text { (internal legal acts) and external audit of systems and controls for } \\
\text { compliance with the AML/CFT Law (Article } 23.2 \text { ) for DNFBPs with less than } \\
10 \text { employees. }\end{array}$ \\
\hline $\begin{array}{l}\text { Suspicious transaction reporting } \\
\text { R.16-PC }\end{array}$ & $\begin{array}{l}\text { - Issuing guidelines on the manner of reporting for dealers in precious stones or } \\
\text { precious metals and relevant typologies of STs for DNFBPs; } \\
\text { - Instigating outreach by way of supervision, training or other means to ensure }\end{array}$ \\
\hline
\end{tabular}




\begin{tabular}{|c|c|}
\hline & $\begin{array}{l}\text { that a clear differentiation is in place between TR and ST reporting } \\
\text { obligations including no thresholds for STR obligations, ST for attempted } \\
\text { transactions and those suspicious with respect to tax matters. }\end{array}$ \\
\hline $\begin{array}{l}\text { Regulation, supervision, } \\
\text { monitoring, and sanctions } \\
\text { R.24 - NC } \\
\text { R.25 - PC }\end{array}$ & $\begin{array}{l}\text { - Designating competent authorities or SROs monitoring and ensuring } \\
\text { compliance with the AML/CFT obligations for independent lawyers and firms } \\
\text { providing legal services, independent accountants and accounting firms; } \\
\text { dealers in precious metals; and dealers in precious stones for effective } \\
\text { monitoring and compliance on a risk sensitive basis; } \\
\text { - Implementing a supervisory regime for advocates (attorneys); } \\
\text { - Introducing for casinos and operators of prize games fitness and propriety } \\
\text { requirements for managers, owners, and beneficial owners including fit and } \\
\text { proper checks for management, owners or beneficial owners. Further, } \\
\text { implementing, by way of law, rules or regulations, requirements that would } \\
\text { prevent criminals or their associates from holding or being beneficial owners } \\
\text { of a significant or controlling interest, holding a management function in, or } \\
\text { being an operator of a casino or operator of a prize game; } \\
\text { - Issuing guidelines for DNFBPs to assist with the full implementation and } \\
\text { compliance of the applicable obligation set forth in the AML/CFT Law; } \\
\text { - Developing relevant feedback processes on number of disclosures and results, } \\
\text { current techniques, methods and trends, or money laundering cases that have } \\
\text { been sanitized relevant to DNFBPs. }\end{array}$ \\
\hline $\begin{array}{l}\text { Other designated non-financial } \\
\text { businesses and professions } \\
\text { R.20 - PC }\end{array}$ & $\begin{array}{l}\text { - Undertaking a risk assessment in order to determine if other NFBPs are at } \\
\text { risk of being misused for ML or TF; } \\
\text { - Take measures to reduce the use of cash and encourage more activity within } \\
\text { the formal sector. }\end{array}$ \\
\hline \multicolumn{2}{|c|}{ 4. Legal Persons and Arrangements \& Nonprofit Organizations } \\
\hline $\begin{array}{l}\text { Legal Persons-Access to beneficial } \\
\text { ownership and control information } \\
\text { R.33 - LC }\end{array}$ & - Amend Article 157 Civil Code to eliminate any reference to bearer shares. \\
\hline $\begin{array}{l}\text { Legal Arrangements-Access to } \\
\text { beneficial ownership and control } \\
\text { information } \\
\text { R.34 - NA }\end{array}$ & - Not Applicable \\
\hline $\begin{array}{l}\text { Nonprofit organizations } \\
\text { SR.VIII - PC }\end{array}$ & $\begin{array}{l}\text { - Establishing outreach to NPOs in relation to the risks of TF abuse and } \\
\text { available measures to protect against TF abuse. }\end{array}$ \\
\hline \multicolumn{2}{|r|}{ 5. National and International Cooperation } \\
\hline $\begin{array}{c}\text { National cooperation and } \\
\text { coordination } \\
\text { R.31 }- \text { LC } \\
\end{array}$ & $\begin{array}{l}\text { - Undertake ongoing analysis of the risk of ML/TF to streamline its AML/CFT } \\
\text { strategy. }\end{array}$ \\
\hline $\begin{array}{l}\text { The Conventions and UN Special } \\
\text { Resolutions } \\
\text { R.35 - PC } \\
\text { SR.I - PC }\end{array}$ & $\begin{array}{l}\text { Put in place confiscation measures for all offenses as defined in the Palermo } \\
\text { Convention; } \\
\text { Provide for the seizing of legitimate property intermingled with proceeds } \\
\text { from or instrumentalities used or intended for use in the commission of crimes } \\
\text { as defined in the Vienna and Palermo Conventions; } \\
\text { - Define the TF offense in line with the definition of the offense in the SFT } \\
\text { Convention; } \\
\text { - Put in place adequate measures to fully address the requirements under } \\
\text { UNSCR } 1267 \text { and } 1373 \text {. }\end{array}$ \\
\hline $\begin{array}{l}\text { Mutual Legal Assistance } \\
\text { R.36 - PC } \\
\text { R.37 - LC } \\
\text { R.38 - PC } \\
\text { SR.V - PC }\end{array}$ & $\begin{array}{l}\text { - Clarify whether dual criminality is required for the provision of mutual legal } \\
\text { assistance to determine whether the deficiencies identified with respect to the } \\
\text { ML and TF offenses as outlined under Recommendations } 1,2 \text { and Special } \\
\text { Recommendation II may limit Armenia's ability to provide assistance in } \\
\text { certain situations, and in particular the ability to provide mutual legal } \\
\text { assistance for proceedings against legal persons. }\end{array}$ \\
\hline
\end{tabular}




\begin{tabular}{|c|c|}
\hline $\begin{array}{c}\text { Extradition } \\
\text { R.39 - C } \\
\text { R.37 - LC } \\
\text { SR.V - PC }\end{array}$ & $\begin{array}{l}\text { - Remedy the deficiencies in the TF offenses to ensure that the dual criminality } \\
\text { requirement does not limit Armenia's ability to extradite persons in TF cases. }\end{array}$ \\
\hline $\begin{array}{c}\text { Other Forms of Cooperation } \\
\text { R.40 - LC } \\
\text { SR.V - PC }\end{array}$ & $\begin{array}{l}\text { Clarify the provisions of professional secrecy, which may hamper FMC's ability } \\
\text { to have access/compel information. }\end{array}$ \\
\hline \multicolumn{2}{|r|}{ 6. Other Issues } \\
\hline $\begin{array}{c}\text { Resources \& Statistics } \\
\text { R.30 - PC } \\
\text { R.32 - NC }\end{array}$ & $\begin{array}{l}\text { - Identify and recruit additional resources to provide for an adequate level of } \\
\text { AML/CFT supervision for both off-site surveillance activities and on-site } \\
\text { inspections; } \\
\text { - Consider additional resources for the FMC; } \\
\text { - Provide AML/CFT specific training for officials of the NSS's investigative } \\
\text { department and the Custom's inquest and investigation departments; } \\
\text { - Maintain accurate statistics. }\end{array}$ \\
\hline
\end{tabular}

